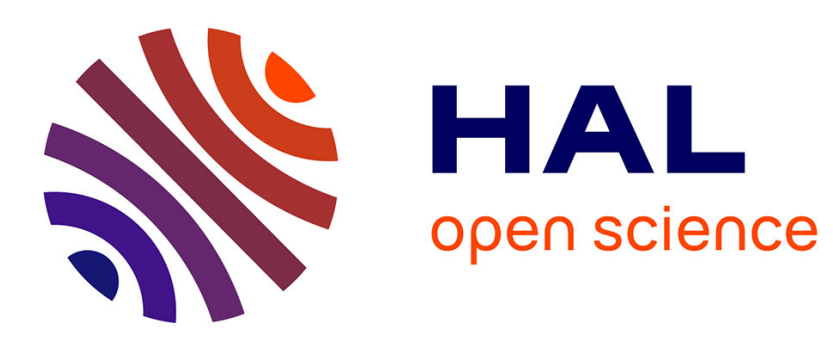

\title{
Comment on "Roles of Hydration and Magnetism on the Structure of Ferrihydrite from First Principles"
}

Alain Manceau

\section{To cite this version:}

Alain Manceau. Comment on "Roles of Hydration and Magnetism on the Structure of Ferrihydrite from First Principles". ACS Earth and Space Chemistry, 2019, 3 (8), pp.1576-1580. 10.1021/acsearthspacechem.9b00018 . hal-02314777

\section{HAL Id: hal-02314777 \\ https://hal.science/hal-02314777}

Submitted on 13 Oct 2019

HAL is a multi-disciplinary open access archive for the deposit and dissemination of scientific research documents, whether they are published or not. The documents may come from teaching and research institutions in France or abroad, or from public or private research centers.
L'archive ouverte pluridisciplinaire $\mathbf{H A L}$, est destinée au dépôt et à la diffusion de documents scientifiques de niveau recherche, publiés ou non, émanant des établissements d'enseignement et de recherche français ou étrangers, des laboratoires publics ou privés. 


\title{
Comment on "The Roles of Hydration and Magnetism on the Structure of Ferrihydrite from First Principles"
}

\author{
Alain Manceau \\ ISTerre, Université Grenoble Alpes, CNRS, CS 40700, 38058 Grenoble, France \\ E-mail: alain.manceau@univ-grenoble-alpes.fr. Phone: +334766351 12.
}

Keywords: Ferrihydrite, structure, diffraction, magnetism, PDF, DFT.

Sassi and Rosso ${ }^{1}$ asserted to have rediscovered the akdalaite model of Michel and coworkers ${ }^{2,3}$ for the structure of ferrihydrite having a composition of $\mathrm{Fe}_{5} \mathrm{O}_{8} \mathrm{H} \cdot n \mathrm{H}_{2} \mathrm{O}(0 \leq n \leq 2)$ using ab initio calculations. Here, we show that the predicted polyhedral configuration and magnetic properties of the lowest enthalpy model correspond to those of hydromaghemite, not ferrihydrite. This is demonstrated by compiling results published in eleven uncited articles by seven independent research groups (Table 1). Taken together, the results in these articles validate the model structure of ferrihydrite obtained by X-ray diffraction ${ }^{4}$ (Drits model) and do not support the model obtained from pair distribution function (PDF) analysis ${ }^{2,3}$ (Michel model). The results pertain to the chemical composition and structure of ferrihydrite, and are synthesized below in five statements that counter some of the hypotheses, statements, and interpretations in Sassi and Rosso. ${ }^{1}$

\section{The average composition of ferrihydrite is $\mathrm{FeOOH} \cdot 0.2-0.4 \mathrm{H}_{2} \mathrm{O}$}

The ferrihydrite models generated by Sassi and Rosso ${ }^{1}$ lie inside the compositional field $\mathrm{Fe}_{5} \mathrm{O}_{8} \mathrm{H} \cdot n \mathrm{H}_{2} \mathrm{O}(0 \leq n \leq 2,0.2 \leq \mathrm{OH} / \mathrm{Fe} \leq 1)$. The $\mathrm{Fe}_{5} \mathrm{O}_{8} \mathrm{H}$ stoichiometry is that of the Michel model, which is depleted in $\mathrm{OH}$ and $\mathrm{H}_{2} \mathrm{O}$. ${ }^{5}$ Six-line ferrihydrite has a mineral core close to $\mathrm{FeOOH}$ and on average 0.2 to 0.4 chemisorbed $\mathrm{H}_{2} \mathrm{O}$ molecules. ${ }^{6}$ The two boundary compositions can be rewritten as $\mathrm{Fe}_{5} \mathrm{O}_{8} \mathrm{H} \cdot 3 \mathrm{H}_{2} \mathrm{O}(\mathrm{OH} / \mathrm{Fe}=1.4)$ and $\left.\mathrm{Fe}_{5} \mathrm{O}_{8} \mathrm{H} \cdot 4 \mathrm{H}_{2} \mathrm{O}(\mathrm{OH} / \mathrm{Fe})=1.8\right)$. Thus, the actual compositional range of ferrihydrite is outside the calculation range. Sassi and Rosso ${ }^{1}$ show that the Fe coordination is influenced by the $\mathrm{OH} / \mathrm{Fe}$ ratio, a ratio typically $\leq 1$ favoring the formation of tetrahedral $\mathrm{Fe}$ as it exists in the Michel model, and a higher ratio favoring the octahedral coordination. Therefore, one would 
not expect a model to have emerged from the calculations in support of the Drits ferrihydrite structure which lacks tetrahedral Fe.

\section{Well-crystallized ferrihydrite has seven diffraction lines}

Sassi and Rosso ${ }^{1}$ consider that ferrihydrite exhibits at most six diffraction lines (6Fh) when in reality it contains seven lines (7Fh) when well crystallized (Fig. 1a,b). ${ }^{7-10}$ The 100 and 101 diffraction lines are broad and partly overlap in 6Fh whereas they are sharp and well-separated in 7Fh. The Xray diffraction (XRD) patterns of $6 \mathrm{Fh}$ and $7 \mathrm{Fh}$ are both fit well by the Drits model, ${ }^{4,8}$ whereas the XRD patterns calculated for the fhyd6 and ferrifh structures of the Michel model contain 14-15 diffraction peaks instead of 7 in the ${ }^{\circ} 2 \theta$ interval of 7 Fh (Fig. 1d,e). ${ }^{11}$

\section{3. "Ferrimagnetic ferrihydrite" is hydromaghemite}

In 2012, the authors of the 2010 study on ferrifh ${ }^{3}$ acknowledged $^{12}$ that the ferrifh sample is not ferrihydrite, but instead is a material previously referred to as hydromaghemite $\left(\gamma-\mathrm{Fe}_{2} \mathrm{O}_{3} \cdot 0.3 \mathrm{H}_{2} \mathrm{O}\right.$ or $\left.\mathrm{Fe}_{5} \mathrm{O}_{8} \mathrm{H} \cdot 0.25 \mathrm{H}_{2} \mathrm{O}^{13}\right)$, based on the resemblance of its XRD pattern with maghemite $\left(\gamma-\mathrm{Fe}_{2} \mathrm{O}_{3}\right)$ and similar ferrimagnetic properties. Therefore, the designation of "ferrimagnetic ferrihydrite" for sample ferrifh is a misnomer and a source of confusion in the Sassi and Rosso article. ${ }^{1}$

Ferrifh is an intermediate ferrimagnetic phase obtained by hydrothermal transformation of ferrihydrite with two diffraction lines (2Fh) when doped with phosphate or citrate. ${ }^{12-15}$ The 2010 study of Michel et al. ${ }^{3}$ was revisited recently in a study using in situ total scattering and PDF analysis. ${ }^{16}$ 2Fh obtained at room temperature from the hydrolysis of Fe salt consists of corner- and edge-linked Fe octahedra $\left({ }^{\mathrm{VI}} \mathrm{Fe}\right) .{ }^{17-19}$ In the absence of phosphate or citrate, 2Fh transforms into antiferromagnetic hematite $\left(\alpha_{-}{ }^{\mathrm{VI}} \mathrm{Fe}_{2} \mathrm{O}_{3}\right)$ under hydrothermal treatment. ${ }^{20,21}$ When present, the two anions are bonded to the Fe octahedra which triggers the appearance of tetrahedral iron $\left({ }^{\mathrm{IV}} \mathrm{Fe}\right)$ and formation of ferrifh, and ultimately of ferrimagnetic $\gamma_{-}{ }^{\mathrm{IV} / \mathrm{VI}} \mathrm{Fe}_{2} \mathrm{O}_{3}$, as heat is applied. Therefore, tetrahedral $\mathrm{Fe}$ is not constitutive of the structure of ferrihydrite. Rather, this coordination is induced by citrate and phosphate.

Is ferrifh described by the akdalaite model? The akdalaite space group $\left(P 6_{3} m c\right)$ was used by Michel et al. to fit both the PDF of fhyd $6,{ }^{2}$ which is six line ferrihydrite (6Fh), and the PDF of ferrifh, ${ }^{3}$ which is hydromaghemite. Therefore, either the PDF technique lacks the sensitivity needed to differentiate these two materials, despite their having distinct XRD patterns, or the analyses of the PDFs of fhyd6 and ferrifh data are questionable. This point was addressed by remeasuring and refitting the PDF of 
6Fh. ${ }^{22}$ The conclusion of this latter study was that the fits of the PDFs of fhyd $6^{2}$ and ferrifh ${ }^{3}$ were overparametrized. Thus, the mathematical solutions were non-unique, and the regressed akdalaite structures of fhyd6 and ferrifh are problematic.

We conclude from this that the sentence "Out of this [modeling] exercise, not only is the Michel model objectively "discovered", but critical analysis of the three most energetically competitive hypothetical new structures on the basis of their theoretical XRD patterns and PDF shows that among the four only the Michel model is capable of describing ferrihydrite observables" in the Sassi and

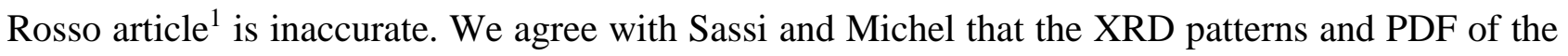
three new magnetic structures differ from ferrihydrite observables (Fig. 1f-h and Fig. 2). However, neither structure refined from the PDFs of the two separate samples (fhyd6 and ferrifh) of Michel and coworkers replicates the XRD pattern of ferrihydrite (Fig. 1d,e). Furthermore, the PDF fits of both samples are unconstrained, which allows an infinite number of structural solutions within the akdalaite space group. ${ }^{22}$

\section{Ferrihydrite is antiferromagnetic, not ferrimagnetic}

It is well established that ferrihydrite is antiferromagnetic with a small magnetic moment of a few $\mathrm{Am}^{2} \cdot \mathrm{kg}^{-1}$ at $2 \mathrm{~K}$ due to uncompensated spin moments. ${ }^{7,23,24}$ The antiferromagnetic structure of ferrihydrite was confirmed recently by magnetization measurements of hexaferrite-ferrihydrite powders. ${ }^{8-10}$ The net magnetic moment decreases when the proportion of ferrihydrite increases in the powder, while it should remain constant or increase if ferrihydrite were ferrimagnetic. Therefore, the ferrimagnetic triclinic structure of Sassi and Rosso ${ }^{1}$ does not provide direct insight into the structure of ferrihydrite.

\section{The Drits XRD model has been confirmed by neutron and X-ray Rietveld refinement, electron nanodiffraction, and HAADF-STEM imaging}

According to the Drits model, ${ }^{4}$ ferrihydrite is a mixture of a defect-free phase (f-phase) and a defective phase (d-phase). The volume percentages of the two components were estimated to be 67:33 for the Drits sample (6Fh) studied by $\mathrm{XRD},{ }^{4}$ and 50:50 for the Jansen sample studied by neutron diffraction. ${ }^{25}$ Ferrihydrite with dominant d-phase has been synthesized. ${ }^{4,26}$ The two phases have been observed by electron microscopy. ${ }^{10,27-29}$

The d-phase has a feroxyhite-type $(\delta-\mathrm{FeOOH})$ local structure with face-sharing octahedral pairs like those described in the antiferromagnetic monoclinic model of Sassi and Rosso. ${ }^{1}$ The d-phase was 
described in terms of a "double chain structure" by Janney et al. in $2000^{27}$, but in reality the polyhedral association is the same as in the d-phase model. ${ }^{30,31}$ The mineral core composition of the f-phase model is $\mathrm{FeO}_{0.85} \mathrm{OH} .{ }^{4}$ The f-phase was used recently in Rietveld fitting of the 7Fh XRD pattern, ${ }^{8}$ and its structure imaged for the first time in 2018 using high-angle annular dark-field imaging in a scanning transmission electron microscope (HAADF-STEM). ${ }^{10}$ The f-phase and akdalaite model have the same projection of the Fe columns along the [001] zone axis, but not along the [010] direction (Fig. 3). Edgewise imaging of a single 7Fh platelet shows that the Fe atoms are distributed as in the f-phase, which is exceptionally strong support for the Drits model (Fig. 3).

The Drits model excludes tetrahedral Fe from ferrihydrite, in agreement with the $\mathrm{OH} / \mathrm{Fe}$ ratio of the mineral core. The tetrahedral coordination, which has been firmly established by X-ray magnetic circular dichroism (XMCD), ${ }^{24,32}$ can be attributed to $\gamma-\mathrm{Fe}_{2} \mathrm{O}_{3}$ and $\mathrm{Fe}_{3} \mathrm{O}_{4}$ impurities, as observed by electron microscopy. ${ }^{28,29,33}$ Tetrahedral $\mathrm{Fe}$ at the ferrihydrite surface has been dismissed using integral low-energy electron Mössbauer (ILEEM) spectroscopy, ${ }^{34}$ in agreement with previous suggestion from x-ray absorption near-edge structure (XANES) spectroscopy. ${ }^{35}$ XMCD does not allow quantification of the amount of tetrahedral $\mathrm{Fe}$ in a coordination mixture. This amount was estimated to be $20-30 \%$ on the basis of an earlier extended X-ray absorption fine structure (EXAFS) study. ${ }^{36}$ However, re-analysis of the EXAFS data reduction showed that this fraction is likely overestimated. ${ }^{30,37}$

Sassi and Rosso ${ }^{1}$ wrote in their introduction that "Although the Drits and Michel models each show generally satisfying agreement with XRD and PDF, respectively, neither agree fully with both measurements simultaneously". We have shown that the Michel model fails to reproduce the XRD pattern of ferrihydrite and that the PDF fits $^{2,3}$ are unconstrained. The Drits model gives good agreement with XRD and fair agreement with PDF. Imperfection in the fit of the PDF of ferrihydrite results from the difficulty of simulating nonperiodic structures. ${ }^{22,38}$ In their conclusion, Sassi and Rosso $^{1}$ recognize the necessity to explore a wider region of compositional space to address the structure of ferrihydrite adequately. Any realistic ferrihydrite model should also incorporate structural defects, such as the mixture of $\alpha / \beta / \gamma-\mathrm{FeOOH}$ building blocks, ${ }^{30}$ point defects (interstitial atoms or vacancies), random occupation of crystallographic sites, stacking faults which alter the periodic sequence of atomic layers, and the mixed-layering of the f-phase and d-phase components. This information, which can be obtained from the modeling of diffraction profiles, ${ }^{4}$ is challenging to generate by atomistic modeling techniques. 


\section{References}

(1) Sassi, M.; Rosso, K. M., Roles of hydration and magnetism on the structure of ferrihydrite from First Principles. ACS Earth Space Chem. 2018, 3, 70-78.

(2) Michel, F. M.; Ehm, L.; Antao, S. M.; Lee, P. L.; Chupas, P. J.; Liu, G.; Strongin, D. R.; Schoonen, M. A. A., et al., The structure of ferrihydrite, a nanocrystalline material. Science 2007, 316, 1726-1729.

(3) Michel, F. M.; Barrónc, V.; Torrent, J.; Moralesd, M. P.; Sernad, C. J.; Boilye, J. F.; Liuf, Q.; Ambrosinig, A., et al., Ordered ferrimagnetic form of ferrihydrite reveals links among structure, composition, and magnetism. PNAS 2010, 107, 2787-2792.

(4) Drits, V. A.; Sakharov, B. A.; Salyn, A. L.; Manceau, A., Structural model for ferrihydrite. Clay Mineral. 1993, 28, 185-208.

(5) Rancourt, D. G.; Meunier, J. F., Constraints on structural models of ferrihydrite as a nanocrystalline material. Am. Mineral. 2008, 93, 1412-1417.

(6) Hiemstra, T.; Van Riemsdijk, W. H., A surface structural model for ferrihydrite I: Sites related to primary charge, molar mass, and mass density. Geochim. Cosmochim. Acta 2009, 73, 4423-4436.

(7) Berquo, T. S.; Banerjee, S. K.; Ford, R. G.; Penn, R. L.; Pichler, T., High crystallinity Siferrihydrite: An insight into its Néel temperature and size dependence of magnetic properties. $J$. Geophys. Res. 2007, 112, B02102.

(8) Granados-Miralles, C.; Saura-Muzquiz, M.; Bojesen, E. D.; Jensen, K. M. O.; Andersen, H. L.; Christensen, M., Unraveling structural and magnetic information during growth of nanocrystalline $\mathrm{SrFe}_{12} \mathrm{O}_{19}$. J. Mater. Chem. C 2016, 4, 10903-10913.

(9) Grindi, B.; Beji, Z.; Viau, G.; BenAli, A., Microwave-assisted synthesis and magnetic properties of $\mathrm{M}-\mathrm{SrFe}_{12} \mathrm{O}_{19}$ nanoparticles. J. Magn. Magn. Mater. 2018, 449, 119-126.

(10) Grindi, B.; BenAli, A.; Magen, C.; Viau, G., M-SrFe ${ }_{12} \mathrm{O}_{19}$ and ferrihydrite-like ultrathin nanoplatelets as building blocks for permanent magnets: HAADF-STEM study and magnetic properties. J. Solid. State Chem. 2018, 264, 124-133.

(11) Manceau, A., Critical evaluation of the revised akdalaite-model for ferrihydrite - Reply. Am. Mineral. 2012, 97, 255-256.

(12) Barron, V.; Torrent, J.; Michel, F. M., Critical evaluation of the revised akdalaite model for ferrihydrite-Discussion. Am. Mineral. 2012, 97, 253-254.

(13) Barron, V.; Torrent, J.; de Grave, E., Hydromaghemite, an intermediate in the hydrothermal transformation of 2-line ferrihydrite into hematite. Am. Mineral. 2003, 88, 1679-1688.

(14) Barron, V.; Torrent, J., Evidence for a simple pathway to maghemite in Earth and Mars soils. Geochim. Cosmochim. Acta 2002, 66, 2801-2806.

(15) Liu, Q.; Barron, V.; Torrent, J.; Eeckhout, S. G.; Deng, C., Magnetism of intermediate hydromaghemite in the transformation of 2-line ferrihydrite into hematite and its paleoenvironmental implications. J. Geophys. Res. 2008, 113, B01103.

(16) Jensen, K. M. O.; Andersen, H. L.; Tyrsted, C.; Bojesen, E. D.; Dippel, A. C.; Lock, N.; Billinge, S. J. L.; Iversen, B. B., et al., Mechanisms for iron oxide formation under hydrothermal conditions: An in situ total scattering study. Acs Nano 2014, 8, 10704-10714. 
(17) Combes, J. M.; Manceau, A.; Calas, G.; Bottero, J. Y., Formation of ferric oxides from aqueous solutions: A polyhedral approach by X-ray absorption spectroscopy: 1. Hydrolysis and formation of ferric gels. Geochim. Cosmochim. Acta 1989, 53, 583-594.

(18) Bottero, J. Y.; Manceau, A.; Villieras, F.; Tchoubar, D., Structure and mechanism of nucleation of $\mathrm{FeOOH}(\mathrm{Cl})$ polymers. Langmuir 1994, 10, 316-319.

(19) Rose, J.; Manceau, A.; Masion, A.; Bottero, J. Y., Structure and mechanisms of formation of $\mathrm{FeOOH}\left(\mathrm{NO}_{3}\right)$ oligomers in the early stages of hydrolysis. Langmuir 1997, 13, 3240-3246.

(20) Combes, J. M.; Manceau, A.; Calas, G., Formation of ferric oxides from aqueous solutions : a polyhedral approach by X-ray absorption spectroscopy. II. Hematite formation from ferric gels. Geochim. Cosmochim. Acta 1990, 54, 1083-1091.

(21) Andersen, H. L.; Jensen, K. M. O.; Tyrsted, C.; Bojesen, E. D.; Christensen, M., Size and size distribution control of $\gamma-\mathrm{Fe}_{2} \mathrm{O}_{3}$ nanocrystallites: An in situ study. Cryst. Growth Des. 2014, 14, 13071313.

(22) Manceau, A.; Skanthakumar, S.; Soderholm, L., PDF analysis of ferrihydrite: Critical assessment of the under-constrained akdalaite model. Am. Mineral. 2014, 99, 102-108.

(23) Guyodo, Y.; Banerjee, S. K.; Lee Penn, R.; David Burleson; Berquo, T. S.; Seda, K.; Solheid, P., Magnetic properties of synthetic six-line ferrihydrite nanoparticles. Phys. Earth Planet. Inter. 2006, 154, 222-233.

(24) Guyodo, Y.; Sainctavit, P.; Arrio, M. A.; Carvallo, C.; Penn, R. L.; Erbs, J. J.; Forsberg, B. S.; Morin, G., et al., X-ray magnetic circular dichroism provides strong evidence for tetrahedral iron in ferrihydrite. Geochem. Geophys. Geosys. 2012, 13, Q06Z44.

(25) Jansen, E.; Kyek, A.; Schafer, W.; Schwertmann, U., The structure of six-line ferrihydrite. Applied Physics A-Materials Science \& Processing 2002, 74, S1004-S1006.

(26) Koch, C. J. W.; Borggaard, O. K.; Madsen, M. B.; Morup, S., Magnetic properties of synthetic feroxyhite ( $\delta$ '-FeOOH). Proceed. Intern. Clay Conf., Denver 1987, 212-220.

(27) Janney, D. E.; Cowley, J. M.; Buseck, P. R., Structure of synthetic 2-line ferrihydrite by electron nanodiffraction. Am. Mineral. 2000, 85, 1180-1187.

(28) Cowley, J. M.; Janney, D. E.; Gerkin, R. C.; Buseck, P. R., The structure of ferritin cores determined by electron nanodiffraction. J. Str. Biol. 2000, 131, 210-216.

(29) Janney, D. E.; Cowley, J. M.; Buseck, P. R., Structure of synthetic 6-line ferrihydrite by electron nanodiffraction. Am. Mineral. 2001, 86, 327-335.

(30) Manceau, A., Critical evaluation of the revised akdalaite-model for ferrihydrite. Am. Miner. 2011, 96, 521-533.

(31) Manceau, A., Evaluation of the structural model for ferrihydrite derived from real-space modelling of high-energy X-ray diffraction data. Clay Mineral. 2009, 44, 19-34.

(32) Cao, L.; Jiang, Z. X.; Du, Y. H.; Yin, X. M.; Xi, S. B.; Wen, W.; Roberts, A. P.; Wee, A. T. $\mathrm{S}$., et al., Origin of magnetism in hydrothermally aged 2-line ferrihydrite suspensions. Environ. Sci. Technol. 2017, 51, 2643-2651.

(33) Janney, D. E.; Cowley, J. M.; Buseck, P. R., Transmission electron microscopy of synthetic 2- and 6-line ferrihydrite. Clays Clay Mineral. 2000, 48, 111-119.

(34) De Grave, E.; Vandenberghe, R. E.; Dauwe, C., ILEEMS: Methodology and applications to iron oxides. Hyperfine Inter. 2005, 161, 147-160. 
(35) Manceau, A.; Gates, W., Surface structural model for ferrihydrite. Clays Clay Mineral. 1997, 43, 448-460.

(36) Maillot, F.; Morin, G.; Wang, Y.; Bonnin, D.; Ildefonse, P.; Chaneac, C.; Calas, G., New insight into the structure of nanocrystalline ferrihydrite: EXAFS evidence for tetrahedrally coordinated iron(III). Geochim. Cosmochim. Acta 2011, 75, 2708-2720.

(37) Paktunc, D.; Manceau, A.; Dutrizac, J., Incorporation of Ge in ferrihydrite: Implications for the structure of ferrihydrite. Am. Mineral. 2013, 98, 859-869.

(38) Billinge, S. J. L.; Kanatzidis, M. G., Beyond crystallography: the study of disorder, nanocrystallinity and crystallographically challenged materials with pair distribution functions. Chem. Commu. 2004, 7, 749-760.

(39) Farrow, C. L.; Juhas, P.; Liu, J. W.; Bryndin, D.; Bozin, E. S.; Bloch, J.; Proffen, T.; Billinge, S. J. L., PDFfit2 and PDFgui: computer programs for studying nanostructure in crystals. J. Phys.: Condens. Mat. 2007, 19, 335219. 
Table 1. Key articles on the structure and magnetic properties of ferrihydrite uncited in the Sassi and Rosso article. ${ }^{1}$

\begin{tabular}{|c|c|c|c|}
\hline Ref \# & Authors & Journal & Title \\
\hline 6 & $\begin{array}{l}\text { Hiemstra and van } \\
\text { Riemsdijk (2009) }\end{array}$ & $\begin{array}{l}\text { Geochim. Cosmochim. } \\
\text { Acta }\end{array}$ & $\begin{array}{l}\text { A surface structural model for ferrihydrite I: Sites related to primary charge, } \\
\text { molar mass, and mass density }\end{array}$ \\
\hline 7 & Berquo et al. (2007) & J. Geophys. Res. & $\begin{array}{l}\text { High crystallinity Si-ferrihydrite: An insight into its Néel temperature and size } \\
\text { dependence of magnetic properties }\end{array}$ \\
\hline 8 & $\begin{array}{l}\text { Granados-Miralles et } \\
\text { al. (2016) }\end{array}$ & J. Mater. Chem. C & $\begin{array}{l}\text { Unraveling structural and magnetic information during growth of } \\
\text { nanocrystalline } \mathrm{SrFe}_{12} \mathrm{O}_{19}\end{array}$ \\
\hline 9 & Grindi et al. (2018) & J. Magn. Magn. Mater. & $\begin{array}{l}\text { Microwave-assisted synthesis and magnetic properties of } \mathrm{M}-\mathrm{SrFe}_{12} \mathrm{O}_{19} \\
\text { nanoparticles }\end{array}$ \\
\hline 10 & Grindi et al. (2018) & J. Solid State Chem. & $\begin{array}{l}\mathrm{M}-\mathrm{SrFe}_{12} \mathrm{O}_{19} \text { and ferrihydrite-like ultrathin nanoplatelets as building blocks for } \\
\text { permanent magnets: HAADF-STEM study and magnetic properties }\end{array}$ \\
\hline 11 & Manceau (2012) & Am. Mineral. & Critical evaluation of the revised akdalaite model for ferrihydrite-Reply \\
\hline 12 & Barron et al. (2012) & Am. Mineral. & Critical evaluation of the revised akdalaite model for ferrihydrite-Discussion \\
\hline 16 & Jensen et al. (2014) & ACS Nano & $\begin{array}{l}\text { Mechanisms for iron oxide formation under hydrothermal conditions: An in } \\
\text { situ total scattering study }\end{array}$ \\
\hline 23 & Guyodo et al. (2006) & Phys. Earth Planet. Inter. & Magnetic properties of synthetic six-line ferrihydrite nanoparticles \\
\hline 27 & Janney et al. (2000) & Am. Mineral. & Structure of synthetic 2 -line ferrihydrite by electron nanodiffraction \\
\hline 30 & Manceau et al. (2011) & Am. Mineral. & Critical evaluation of the revised akdalaite model for ferrihydrite \\
\hline
\end{tabular}




\section{Figure caption}

Figure 1. (a-c) Experimental XRD of samples $6 \mathrm{Fh},{ }^{31}, 7 \mathrm{Fh},{ }^{7}$ and ferrifh ${ }^{3}$. (d,e) Calculated XRD of the fhyd $6^{2}$ and ferrifh ${ }^{3}$ akdalaite models. (f-h) Calculated XRD of the three energetically most stable $\mathrm{Fe}_{10} \mathrm{O}_{16} \mathrm{H}_{n}$ magnetic structures calculated by Sassi and Rosso. ${ }^{1}$ The $\mathrm{Fe}_{10} \mathrm{O}_{16} \mathrm{H}_{2}$ model has the same stoichiometry as the akdalaite models. The XRD traces were calculated with the Mercury program from the Cambridge Crystallographic Data Center (CCDC).

Figure 2. Experimental (sample 6Fh) and calculated PDFs for six-line ferrihydrite. (a) Fit of 6Fh with the Drits model (adapted from Ref. ${ }^{22}$ ). (b) Fit of $6 \mathrm{Fh}$ with the antiferromagnetic orthorhombic model. Scale factor $=1.8$, resolution parameters $q_{\text {damp }}=0.24 \AA^{-1}$ and $q$ broad $=0.06 \AA^{-1}$ (fixed), dynamic correlation factor $\delta=1.1$, isotropic thermal parameters $U_{F e}=0.009 \AA^{2}$ and $U_{O}=0.017 \AA^{2}$. (c) Fit of $6 \mathrm{Fh}$ with the antiferromagnetic monoclinic model. Scale factor $=1.4, q_{\mathrm{damp}}=0.03 \AA^{-1}, q_{\text {broad }}=0.06$ $\AA^{-1}$ (fixed), $\delta=1.8, \mathrm{U}_{\mathrm{Fe}}=0.034 \AA^{2}, \mathrm{U}_{\mathrm{O}}=0.0153 \AA^{2}$. (d) Fit of $6 \mathrm{Fh}$ with the ferrimagnetic triclinic model. Scale factor $=2.9, q_{\text {damp }}=0.13 \AA^{-1}$ (fixed), $q_{\text {broad }}=0.06 \AA^{-1}$ (fixed), $\delta=1.3, \mathrm{U}_{\mathrm{Fe}}=0.024 \AA^{2}$, $\mathrm{Uo}_{\mathrm{O}}=0.074 \AA^{2}$. PDFs were calculated up to $10 \AA$ using the pdfgui ${ }^{39}$ interface and the crystallographic coordinates and lattice values given as supporting information in the Sassi and Rosso article. ${ }^{1}$ The particle size was fixed to $35 \AA$ whereas isotropic thermal and atom-independent parameters were regressed against the experimental PDF data of $6 \mathrm{Fh}^{22}$

Figure 3. (a) Fourier filtered HAADF image of a f-phase nanocrystal oriented in the [001] zone axis. ${ }^{10}$ $(b, c)$ Projection of the Fe columns in the (001) plane of the Drits model (b) and the Michel akdalaite model (c). The two models are indistinguishable in this orientation. (d) Fourier filtered HAADF image of a f-phase nanocrystal viewed on the edge. ${ }^{10}$ (e,f) Projection of the Fe columns in the (010) plane of the Drits model (e) and the Michel akdalaite model (f). Only the Drits model matches the experimental image. 


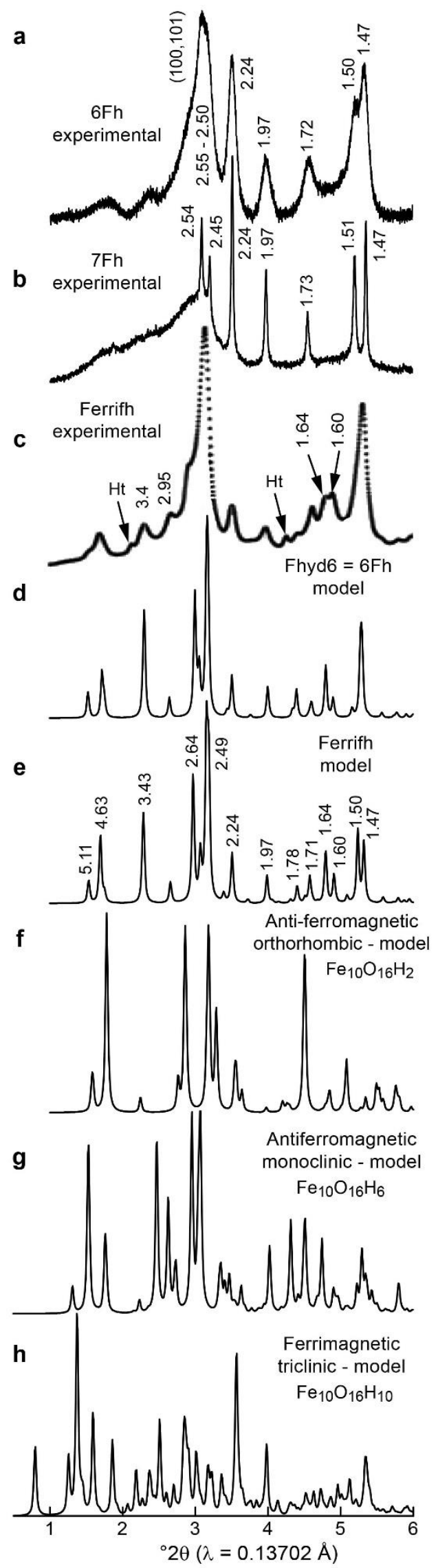

Figure 1 


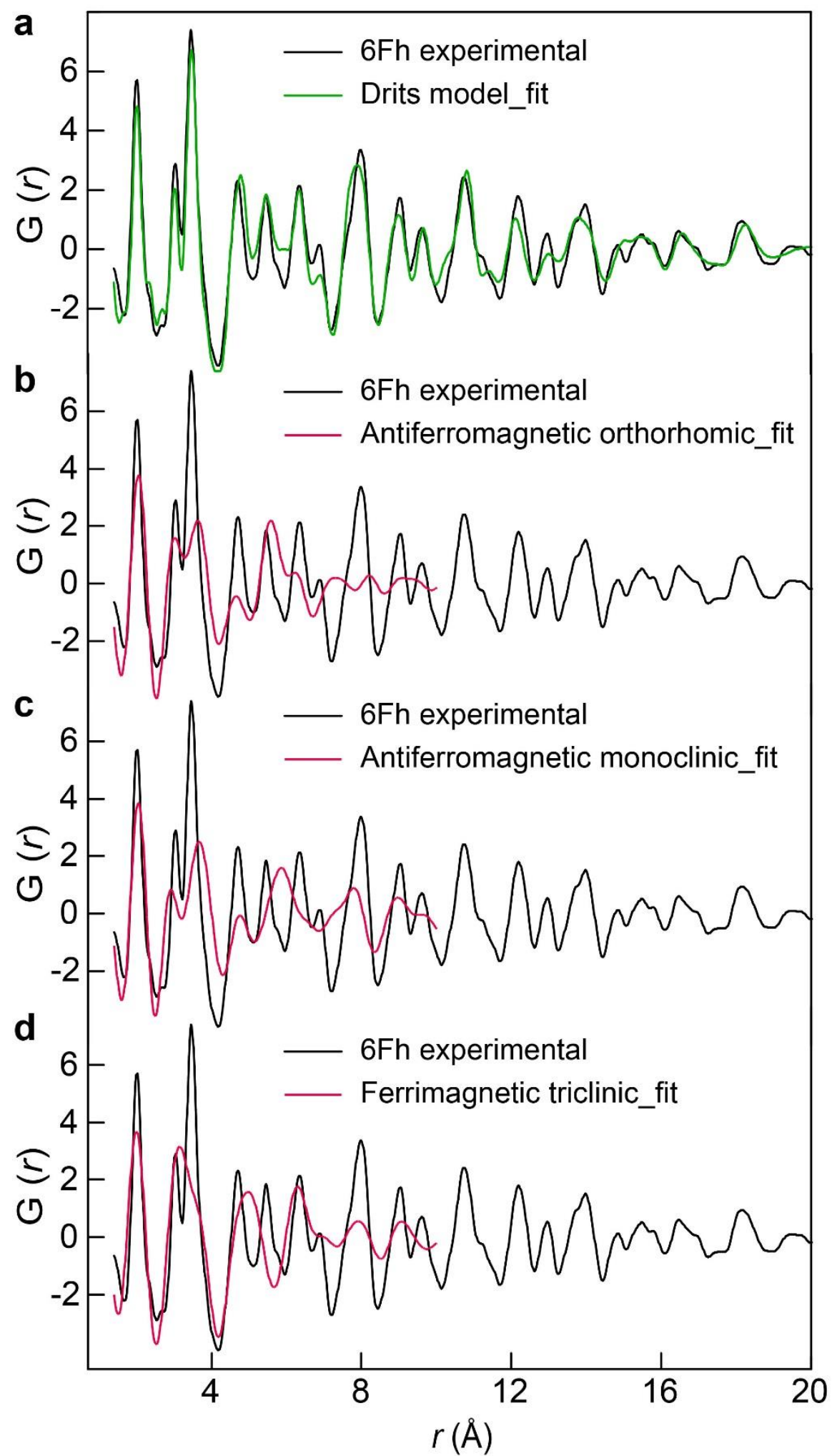

Figure 2 

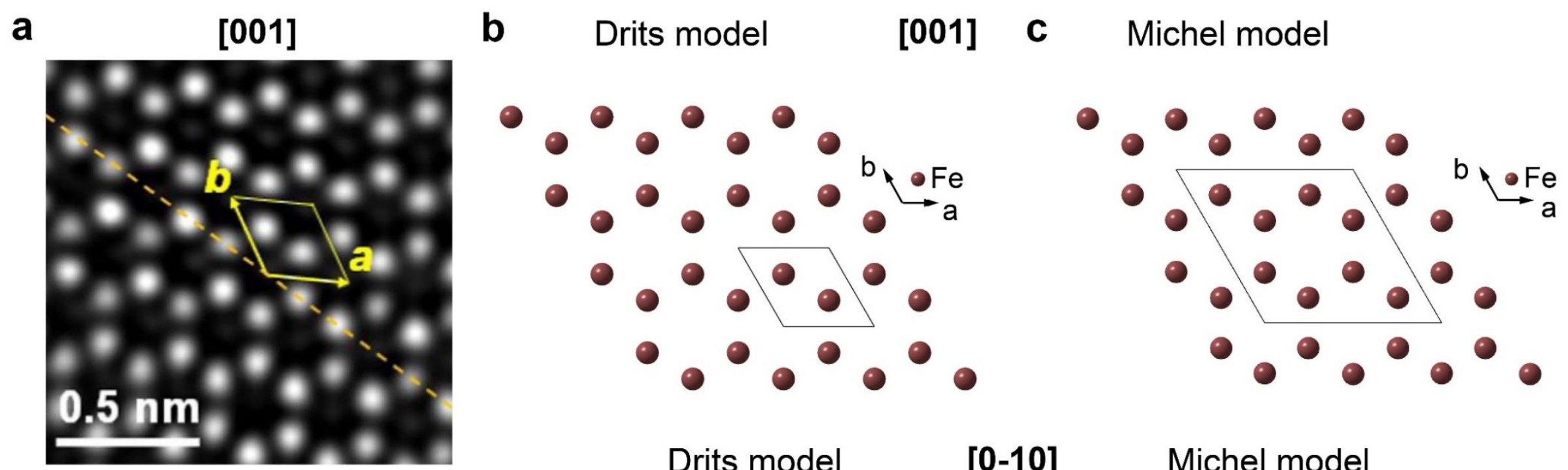

Drits model

- -0

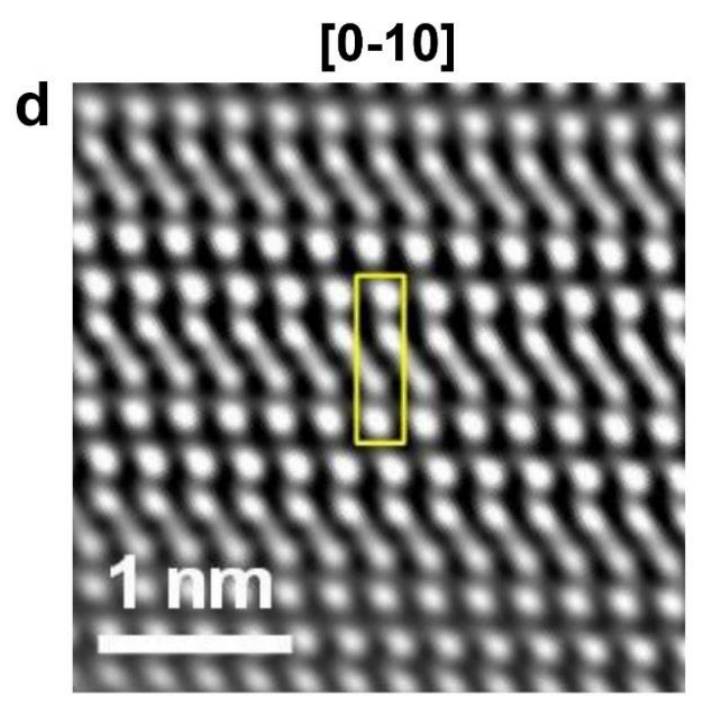

- 0

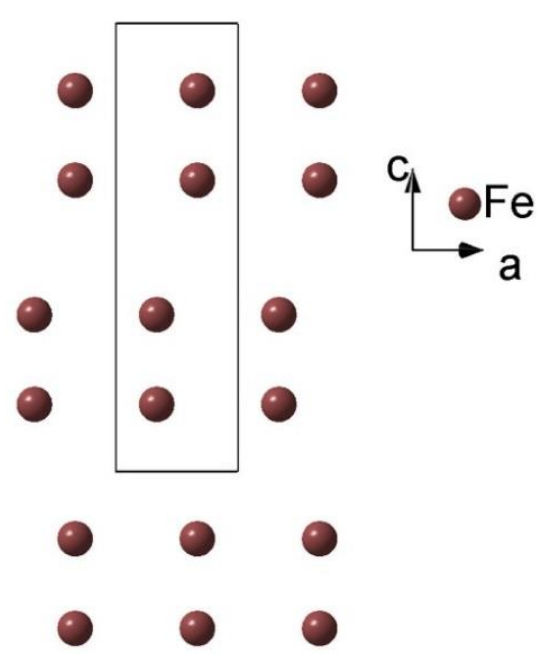

[0-10]

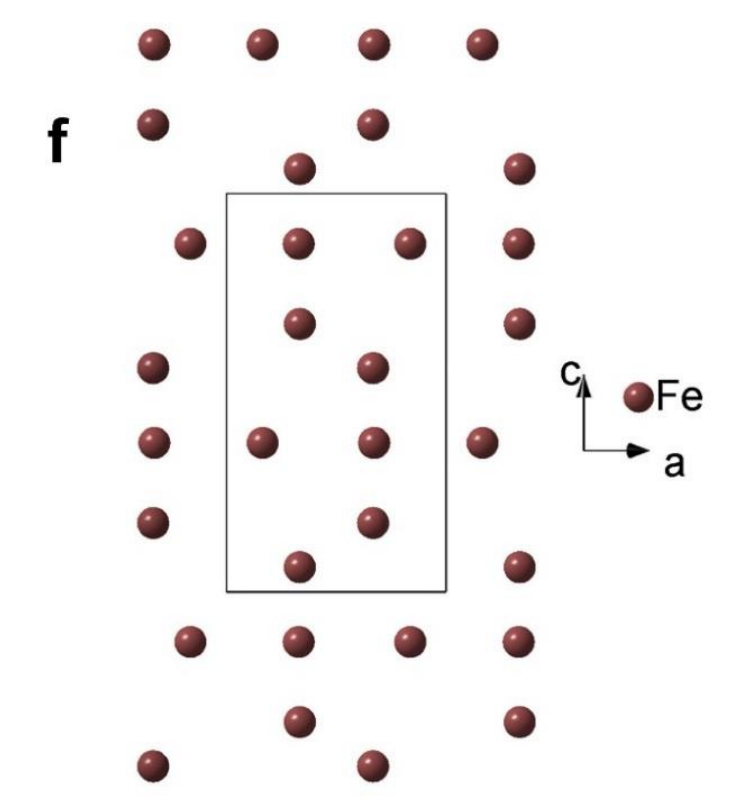

Figure 3 